\title{
Australia
}

\section{"Calidad Pty v. Seiko Epson Corporation"}

\section{Decision of the High Court of Australia}

12 November 2020 - Case No. [2020] HCA 41

\section{Calidad Pty Ltd \& Ors v. Seiko Epson Corporation \&} Anor

Patents Act 1903 (Cth), Sec. 62; Patents Act 1990

(Cth), Secs. 2A, 13, 135, 144, Sch 1

(C) Max Planck Institute for Innovation and Competition, Munich 2021

Keywords Infringement - Exhaustion doctrine - Implied licence doctrine - Make, hire, sell or otherwise dispose of, use, exercise and vend - Re-use and repair .

Overturning case law

1. The implied licence doctrine is not consistent with the certainty demanded by trade and commerce or with consumer expectations, which require the maintenance of the fundamental principle of the law recognising that an owner has full rights as to the use and disposal of a chattel.

2. A patentee's rights with respect to a particular product are exhausted once that product is sold without conditions as to use (exhaustion doctrine).

3. Modifications made to a product are within the scope of the rights of an owner when they are made in order to prolong the life of a product and make it more useful, thus not amounting to an impermissible making of a new product.

Publisher's Note Springer Nature remains neutral with regard to jurisdictional claims in published maps and institutional affiliations. 